\title{
"Critical assessment of risk-taking behavior and economic performance of male entrepreneurs in the Centurion central business district in South Africa"
}

\begin{tabular}{ll} 
AUTHORS & $\begin{array}{l}\text { Johannes Petrus Holtzhausen } \\
\text { Vinessa Naidoo id https://orcid.org/0000-0002-2358-5588 }\end{array}$ \\
\hline ARTICLE INFO & $\begin{array}{l}\text { Johannes Petrus Holtzhausen and Vinessa Naidoo (2016). Critical assessment } \\
\text { of risk-taking behavior and economic performance of male entrepreneurs in the } \\
\text { Centurion central business district in South Africa. Investment Management and } \\
\text { Financial Innovations, 13(3), 93-104. doi:10.21511/imfi.13(3).2016.08 }\end{array}$ \\
\hline DOI & http://dx.doi.org/10.21511/imfi.13(3).2016.08 \\
\hline RELEASED ON & Tuesday, 23 August 2016 \\
\hline JOURNAL & "Investment Management and Financial Innovations" \\
\hline FOUNDER & LLC “Consulting Publishing Company "Business Perspectives"
\end{tabular}

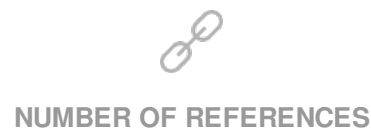

0
NUMBER OF FIGURES

0

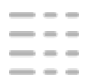

NUMBER OF TABLES

0

(C) The author(s) 2023. This publication is an open access article. 
Johannes Petrus Holtzhausen (South Africa), Vinessa Naidoo (South Africa)

\title{
Critical assessment of risk-taking behavior and economic performance of male entrepreneurs in the Centurion central business district in South Africa
}

\begin{abstract}
According to Zinkhan and Karande (1990), risk is encountered when an individual's action produces social and economic consequences that cannot be projected with certainty. Zinkhan and Karande (1990) also see risk averseness as the propensity to avoid taking risks and are generally conceived as a personality variable. Levitt (1990) argues that the ways in which business managers handle risk can markedly affect economic performance and the standard of living in various societies. It was, thus, imperative that this study coupled risk-taking ability with economic performance amongst male entrepreneurs in Centurion. The entrepreneurial phenomenon remains a widely researched topic. Extensive research with regards to the attributes of entrepreneurs has been done in the recent past. It has, thus, become important to better understand South African entrepreneurial behavior, as not many local studies has been done on the topic. The purpose of this study is to establish whether the identified factors affect the risk taking behavior of male entrepreneurs within the Centurion CBD. The risk-taking behavior of male entrepreneurs versus their economic performance was also investigated. By gaining an understanding of the risk taking behavior of the population, recommendations for future studies could be made. This study is based on a deductive approach to establish possible factors which might affect the risk-taking behavior of male entrepreneurs within the Centurion central business district. It also investigates the relationship between their risk-taking behavior and their economic performance. The researcher established possible factors from the literature and adopted and modified the DOSPERT scale developed by Weber, Blais and Betz (2002). Quantitative data were obtained within the population of 161 respondents. The results indicate a strong correlation between the factors identified and the risk-taking behavior of the entrepreneurs, except for the factor ethnic background. It was also found that a strong relationship exists between risk-taking behavior and economic performance.
\end{abstract}

Keywords: factors, entrepreneur, risk-taking, economic performance.

JEL Classification: M13, D81.

\section{Introduction}

In an Essay on Economic Theory by Richard Cantillon, written in 1755, the entrepreneur is described as, among other things, a risk bearer (Curry, 2014 , p. 1). The notion that risk is a key element of entrepreneurship is seen throughout the entrepreneurial literature (Ahmed, 1985; Caliendo, Fossen, \& Kritikos, 2010; Koh, 1996; Long, 1983). According to Zinkhan and Karande (1990), risk is encountered when an individual's actions produce social and economic consequences that cannot be projected with certainty. Risk averseness is described as the propensity to avoid taking risks and is generally conceived as a personality variable (Zinkhan \& Karande, 1990). Levitt (1990) argues that the ways in which business managers approach risk can markedly affect their economic performance and the standard of living in various societies. Researchers suggested that risk attitudes are domain specific and can be divided into five distinct categories: financial, health/safety, ethics, recreational, and social. In response to the long-standing measurement problems in the literature on risk attitude, Weber and her colleagues introduced the Domain Specific Risk-Taking Scale (DOSPERT)

(C) Johannes Petrus Holtzhausen, Vinessa Naidoo, 2016.

Johannes Petrus Holtzhausen, MBA Student, Tshwane University of Technology, Pretoria, South Africa.

Vinessa Naidoo, Dr., the Acting Director of the Tshwane University of Technology, Business School, Pretoria, South Africa.
(Blais \& Weber, 2006; Weber et al., 2002). In its short existence, the DOSPERT has been highly cited, and has become the risk measure of choice in the literature on judgment and decision making (Appelt, Milch, Handgraaf \& Weber, 2011). A modified questionnaire based on the DOSPERT scale to investigate the risktaking behavior of the respondents has been used for this study. According to Li and Fang (2004) and other researchers, it was established that the Chinese entrepreneurs were found to be more risk seeking than their American counterparts (Weber \& Hsee, 1998; Weber, Hsee \& Sokolowska, 1998; Yates, Lee \& Bush, 1997; Yates, Lee \& Shinotsuka, 1996; Yates, Lee, Shinotsuka, Patalano \& Sieck, 1998). It was found that reliable cultural differences in the pricing of risky options exist, in the sense that between-culture variation was significantly larger than within-culture variation (Weber \& Hsee, 1998, p. 121). Anderson and Eshima (2013) found contingent effect of firm age and intangible resource advantage on the entrepreneurial orientation and firm growth relationship. Intangible resources, resources with no physical substance such as patents, copy rights and brand value, are seen as critical sources which provide the organization with a competitive advantage (Anderson \& Eshima, 2013, p. 418). Younger firms and those that are endowed with an intangible resource advantage, exhibit stronger growth in conjunction with an entrepreneurial strategic posture than older, and more resource disadvantaged firms. 
Entrepreneurs need educational human capital in order to be able to start and operate successful businesses (Chen \& Wu, 2012, p. 1316). A questionnaire was developed to investigate the possible effect of the entrepreneur's age, level of education, access to financial support, ethnic background, operating sector and the firm's years of operation (firm age) on their risk-taking behavior. A quantitative research method based on a deductive approach was applied in order to test the theory against the data. The population consists of male entrepreneurs within the Centurion central business district. Trained field workers were utilized to collect the data, which were analyzed using a SPSS.

\section{Literature review}

According to Cunningham and Lischeron (1991, p. 45 ), there is generally no accepted definition or model of what the entrepreneur is or does. They also state that, in the past decade, a number of trends have emerged which distinguish between individual entrepreneurship and corporate entrepreneurship. It is clear from the literature that the dynamics of entrepreneurship and the role of the entrepreneur have been widely researched. Understanding and explaining the entrepreneurial phenomenon remains a challenging concept to grasp and study. Very little is still known about entrepreneurs, even though there is much interest and many publications on the subject. The material is often fragmented and highly controversial (Cunningham \& Lischeron, 1991). Cunningham and Lischeron (1991) also state that the selection of the appropriate basis for defining and understanding the entrepreneurial person creates a challenge for academic researchers and writers. Carland, Carland and Stewart (1996) suggest that entrepreneurs are not homogenous. They may well be characterized by the need for achievement, the preference for innovation and risk-taking propensity, but some are more driven than others. Webster's Third New International Dictionary (1961) defines an entrepreneur as "the organizer of an economic venture, especially one who organizes, owns, manages, and assumes the risk of a business". Funk and Wagnall's Standard Dictionary (1958) offers a similar definition. It states that an entrepreneur is "one who undertakes to start and conduct an enterprise or business, assuming full control and risks".

Spinelli and Adams (2012, p. 87) state that entrepreneurship is a way of thinking, reasoning, and acting that is opportunity obsessed, holistic in approach, and leadership balanced for the purpose of value creation and capture. They also state that entrepreneurship results in the creation, enhancement, realization and renewal of value, not just for owners, but for all participants and stakeholders. At the heart of the process are the creation and recognition of opportunities, followed by the will and initiative to seize these opportunities. It requires the willingness to take risks. According to Carland et al. (1996), much of the research has been founded upon the basis that entrepreneurs embody distinctive personality characteristics. The earliest identified entrepreneurial characteristic was risk-taking (Carland et al., 1996). The entrepreneur is portrayed as an individual who assumed the risk for the firm. Carland et al. (1996) also offered that risk assessment and risk-taking are the primary elements of entrepreneurship and that risk includes not only financial considerations, but also career opportunities and family relations. Yet, researchers are undecided about the role of the risktaking propensity of entrepreneurs (Brockhaus, 1987). Shane, Locke and Collins (2003) suggest that entrepreneurship involves human agency. The entrepreneurial process occurs, because people act to pursue opportunities, but they differ in their willingness and abilities to act on these prospects, because of their individualism. They argue that the variation among people in their capacity to act has important effects on the entrepreneurial process (Shane et al., 2003).

According to Miao and Liu (2010), entrepreneurial decision making refers to the choices made by entrepreneurs when faced with entrepreneurial opportunities. It has the attributes of conventional decision making, such as risk, process, and irreversibility. However, implicit in entrepreneurial decision making are unique features. It is undeniable that the process from opportunity recognition to entrepreneurial decision making is subject to the moderating effects of other variables (Miao \& Liu, 2010). The results of a study done by Forlani and Mullins (2000) suggest that better understanding is needed about how entrepreneurs search for and process information about business situations and how such information processing influences entrepreneurial behavior. Crant (1996) established that a variety of individual variables are associated with entrepreneurial intentions. For example, they found that gender, education, and entrepreneurial parents were all associated with entrepreneurial intentions. Students who showed higher entrepreneurial intentions tend to be male rather than female. Crant (1996) main findings are concerned with the subjects' proactivity in relation to entrepreneurial intention. Proactivity was positively associated with entrepreneurial intentions. Proactivity was measured based on Bateman and Crant's (1993) 17 item measure. This proactivity scale is intended to identify differences among people in the extent to which they take action to influence their environments.

The question is: "What constitutes risk?" Risk reflects the degree of uncertainty and potential loss associated with the outcomes which may follow from a given behavior or set of behaviors (Forlani \& Mullins, 2000). Yates and Stone (1992) identify three elements of the risk construct: potential losses, the significance of 
those losses, and the uncertainty of those losses. In risky entrepreneurial contexts, where losses are almost always possible, it is the significance of any possible losses - or hazards - and the uncertainty or variability of those losses that are likely to be most significant in driving risk perceptions and risk decision making behavior. The hazard and variability dimensions of risk argue, respectively, that greater potential hazard and greater variability in anticipated returns for a proposed venture should lead entrepreneurs to view the venture as riskier than one having less hazard and less variability, all other factors equal. According to the definition of entrepreneurship and everyday observation, entrepreneurs are perceived as more risk prone than the average person, however, laboratory studies do not provide conclusive support for this claim. (Macko \& Tyszka, 2009). Brockhaus (1980) found by using the Kogan-Wallach questionnaire to measure the propensity of risk taking in the three groups, entrepreneurs, freshly hired managers, and managers who just got promoted, that no significant differences were apparent between these groups. Similarly, when Richard (1989) used Jackson's questionnaire, consisting of 10 true or false statements that concern risk in different areas (social, ethical, financial), he did not find any differences with regard to risk- taking in entrepreneurs and non-entrepreneurs. Macko and Tyszka (2009) confronted their respondents with different scenarios, asking them to choose the riskier one of the two. Their study established that, in terms of risk attitudes, entrepreneurs are not that different from other people. There are even hints indicating that, in a subjective sense, entrepreneurs may take less risk than others.

Alternatively, in other research where measures of risk inclination, similar to that of Macko and Tyszka were used, a difference between entrepreneurs and nonentrepreneurs was found. For example, research, where the same Jackson's questionnaire was applied, confirmed the hypothesis that entrepreneurs have a more positive attitude toward risk than nonentrepreneurs (Begley \& Boyd, 1987; Carland, Carland, Carland \& Pearce, 1995; Stewart, Watson, Carland \& Carland, 1999).

According to Tyszka, Cieslik, Domurat and Mackoa (2011), risk-proneness is not a characteristic specific to entrepreneurs. They argue rather that the fact of being an entrepreneur brings along with it increased risky business activities. This could explain the differing results obtained in various studies concerning entrepreneurs' risk attitudes. They also state that, generally, when the Kogan-Wallach Choice-Dilemma Questionnaire has been used in research, no difference was found between entrepreneurs and nonentrepreneurs. The possible reason for these results is that, in Kogan-Wallach's questionnaire, individuals are asked to indicate acceptable probabilities for taking part in abstract lotteries. Thus, this task is unrelated to a business environment. On the other hand, in research where the Jackson Personality Inventory has been used, entrepreneurs have shown a higher level of risktaking than non-entrepreneurs (Tyszka et al., 2011). According to Palich and Bagby (1995), entrepreneurs and non-entrepreneurs did not differ significantly in their responses to Gomez-Mejia and Balkin's (1989) risk propensity scale. This scale asked subjects to respond to each of four items using a seven-point Likert-type scale ranging from strongly agree to strongly disagree. At the same time, their findings suggest that entrepreneurs tend to derive more positive and optimistic perceptions, compared to others, when presented with identical business scenarios.

Willebrands, Lammers and Hartog (2012) found mixed support for the view: "entrepreneurs who are willing to take risks, will, on average, perform better". Taking the literature into account, they moved towards the view that entrepreneurs distinguishing skills between risk propensity and risk perception are different than those of non-entrepreneurs. For example, Barbosa, Gerhardt and Kickul (2007) found that individuals with a high risk preference have higher levels of entrepreneurial intentions, are more opportunity-seeking and have higher levels of selfefficiency. Individuals with a low risk preference, on the other hand, had higher levels of relationship efficacy and tolerance efficacy. They also found that intuitive individuals with a higher preference for risk exhibited higher levels of opportunity identification efficacy. Forlani and Mullins (2000) provide evidence which extends the work of March and Shapira (1987) that differences in entrepreneurs' new venture choices were influenced not only by differences in the risks inherent in the patterns of anticipated outcomes for different ventures, but also by differences in the entrepreneurs' perceptions of those risks, as well as their willingness to take risks. Weber et al. (2002) provided strong evidence, with their study of 560 undergraduate students by assessing their risk-taking in five different domains, namely financial, health/safety, recreational, ethical, and social, in favor of the hypothesis that risk-taking is domain- specific. This means that, by definition, conventional riskattitudes, i.e., risk attitudes inferred from behavior either directly or via utility functions that are derived from risky choices, are also domain-specific rather than reflections of a stable attitude or trait (Weber et al., 2002). In addition to them, documenting the domain-specificity of risk attitudes for a far more comprehensive set of risk domains than previously compared in a single study, their paper makes three other contributions.

Brockhaus (1980) defines risk-taking propensity as the perceived probability of receiving the rewards associated with success of a proposed situation. An 
individual needs this willingness to take a risk before he will subject himself to the consequences associated with failure.

According to Keil, Wallace, Turk, Dixon-Randol and Nulden (1998), the exact nature of the relationship between risk perception, risk propensity, and decisionmaking is not well- understood. While prior research has examined the effects of risk perception on decisionmaking and the relationship between risk propensities and decisionmaking, they were only aware of one study that has examined all three constructs together (Sitkin \&Weingart, 1995). In this study, Sitkin and Weingart (1995) conducted laboratory experiments in which they manipulated outcome history and problem framing while measuring risk propensity, risk perception, and decisionmaking. The results of their study suggest that risk propensity is inversely related to risk perception which, in turn, is inversely related to the tendency to make risky decisions. No significant effect was found between risk propensity and decisionmaking.

Keil et al. (1998) established two key findings from their study: (1) an individual's risk perception appears to be shaped more by perceived downside potential than the actual probability of failure occurring, and (2) an individual's willingness to pursue a risky project appears to be influenced more by risk perception than by any innate propensity to take or avoid risks. Forlani and Mullins (2000) found that entrepreneurs who have greater risk propensities tend to choose riskier ventures. Risk propensities did not significantly influence their subjects' perceptions of venture risks, contrary to the prediction by Sitkin and Pablo (1992). The absence of an effect of risk propensity on risk perceptions is consistent with the findings of a study by Palich and Bagby (1995) who found a consistently optimistic pattern of categorization of business situations among entrepreneurs compared to nonentrepreneurs (Forlani \& Mullins, 2000).

According to Keil et al. (1998), before discussing the impact of risk perception on decisionmaking, it is necessary to understand how individuals assess, or perceive, risk. Previous research has indicated that perceptions are affected by the degree of risk associated with a situation. This would imply that an individual's risk perception in a given situation will be a function of both the probability of a loss, as well as the potential magnitude of such a loss, should it occur. Blais and Weber (2006) utilized a revised DOSPERT scale to study the risk return relationship between apparent risk-taking and risk perception in five risk domains, namely financial, health/safety, recreational, ethical, and social. The original scale was developed to measure individual differences in attitudes towards risk over these 5 domains (Weber et al., 2002). Blais and Weber (2006) found that the relationship between apparent risk-taking and perception explained a considerable portion of the within-individuals variability in apparent risk-taking. Across domains, respondents were, for the most part, perceived-risk averse or neutral, with some between-individuals variability in perceived-risk attitude.

Willebrands et al. (2012) found robust evidence that higher risk perception leads to better performance due to pre-cautionary action by individuals to contain risk. Weber et al. (2002) provided more evidence for the hypothesis that perceived-risk attitude, which factors domain differences in risk perception out of risk behavior, is significantly more consistent across domains for a particular respondent than conventional risk attitude. Most respondents were significantly or mildly perceived-risk averse in all content domains. What differed between individuals (partly as a function of gender) and between domains were perceptions of the benefits and threats of risky activities. Simon, Houghton and Aquino (1999) asked the question whether cognitive biases lead individuals to perceive different levels of risk. They also studied the variations in risk perception associated with decisions. Their findings were that risk perception do affect decision making and that individuals who perceive lower levels of risks were more likely to form a venture.

\section{Research methodology}

2.1. Data collection approach. A self-administered questionnaire, a modified version of the Weber et al. (2002) study, was used to collect primary data, as well as descriptive statistics with Likert-scale type questions. A random sampling technique was used to collect the data within the population. The questionnaires were self-administered and were supervised by trained field workers within the Centurion CBD. The data were analyzed by means of descriptive statistics, using the Statistical Package for Social Science (SPSS) to determine the frequencies. Further analysis was executed through Cronbach's Alpha coefficient to measure the consistency of the data and casual relationships were analyzed through multiple regression analysis. Factor analysis was done through cross tabulation to determine the factors' dimensions in order to identify factors that influence risk-taking behavior. The procedures applied to conduct the research, based on a deductive approach, the data overview, data analysis and interpretation of the results are discussed. As affirmed by Saunders et al. (2012, p. 163), quantitative research is predominantly obtained from questionnaires when collecting data. A shortened questionnaire, based on that of Weber et al. (2002) was used to obtain quantitive results. Weber et al. (2002) used a psychometric scale to assess risktaking in five content domains: financial decisions (separately for investing versus gambling), health/safety, recreational, ethical, and social 
decisions. Participants were required to complete their biographical profiles as part of the questionnaire without exposing their identity, to ensure anonymity. Participants were informed of and aware that their acceptance and completion of the questionnaire signalled their voluntary participation. The data obtained from the questionnaire were coded and analyzed through the Statistical Package for Social Science. The data analysis covered two issues: factors that might affect entrepreneurial risk-taking and risktaking versus economic performance.

2.2. Data analysis. The data obtained from the questionnaires were coded to ensure they are correctly captured within the SPSS. With the data being translated from raw data into a statistical tool, it is possible to examine relationships and trends. The analysis was conducted subsequently, utilizing SPSS which is a software program well suited for this type of data analysis, under the guidance of an independent statistician. The identification and coding are critical to ensure the Likert style type data could be captured accurately to ensure the correct analysis. The analysis results were exported to Excel and converted into simple, clear graphs and tables for analysis representation.

2.3. Descriptive statistics. The biographical data, which included a section to confirm entrepreneurial involvement and factors that might affect entrepreneurial risk-taking, were examined to have a clear view of the profile of the population obtained from the data collection. This analysis took place through descriptive statistics, mostly applying frequency tables and graphs. Vogt and Johnson (2011, p. 147) define frequency distribution as counting the occurrence each time it is presented in a cluster of data. They explain it as the data that represent attributes for a specific variable. This means that the data describe the specific characteristics of the data received. The data are presented in their frequency number. The frequency number gives an indication of the quantity occurrence.

Entrepreneurial profile. Webster's Third New International Dictionary (1961) defines an entrepre- neur as "the organizer of an economic venture, especially one who organizes, owns, manages, and assumes the risk of a business". In order to confirm that the majority of respondents at least comply with scholar understanding of entrepreneurship, section A of the questionnaire section determined whether the respondent is a business owner who is actively managing a business. It also established the involvement in decision making and whether the respondent sees himself as self-employed. Figure 1 represents the entrepreneurial profile of the respondents after the recoding of section A into one variable. The majority of the respondents fit the profile of an entrepreneur.

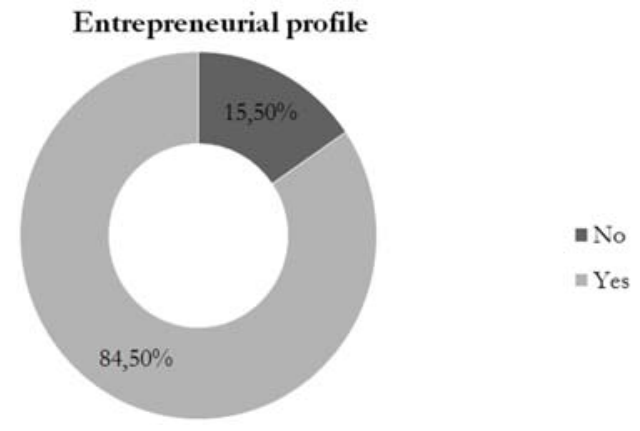

Fig. 1. Entrepreneurial profile of respondents

Spinelli and Adams (2012, p. 87) state that Entrepreneurship is a way of thinking, reasoning, and acting that is opportunity obsessed, holistic in approach, and leadership balanced for the purpose of value creation and capture. They also state that entrepreneurship results in the creation, enhancement, realisation and renewal of value, not just for owners, but for all participants and stakeholders. At the heart of the process are the creation and/or recognition of opportunities, followed by the will and initiative to seize these opportunities.

Frequency tables with regards to factors affecting risk taking ability. Section $\mathrm{B}$ of the questionnaire addresses the factors that might affect risk-taking ability. These factors are age, level of education, access to financial support, ethnical background, number of years in operation and the sector of operation. The frequency of respondents for each variable is shown in Figures 2 to 4.

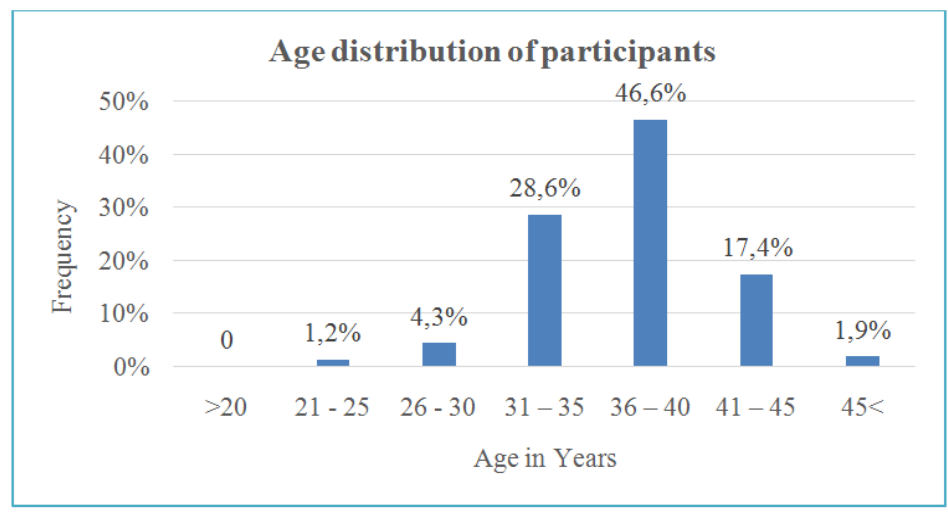

Fig. 2. Age distribution of participants 
The age distribution of the participants found no participants under 20 years of age and $1.2 \%$ in the 21-25 year range. The 26-30 year old group makes up $4.3 \%$ while $28.6 \%$ participants fall in the $31-35$ year range. Most participants are between 36-40 years of age, forming $46.6 \%$ of the population. In the $41-45$ years range there are $17.4 \%$ of the participants with only $1.9 \%$ over the age of 45 years. This data will assist in identifying whether age affects the risk-taking ability of entrepreneurs.

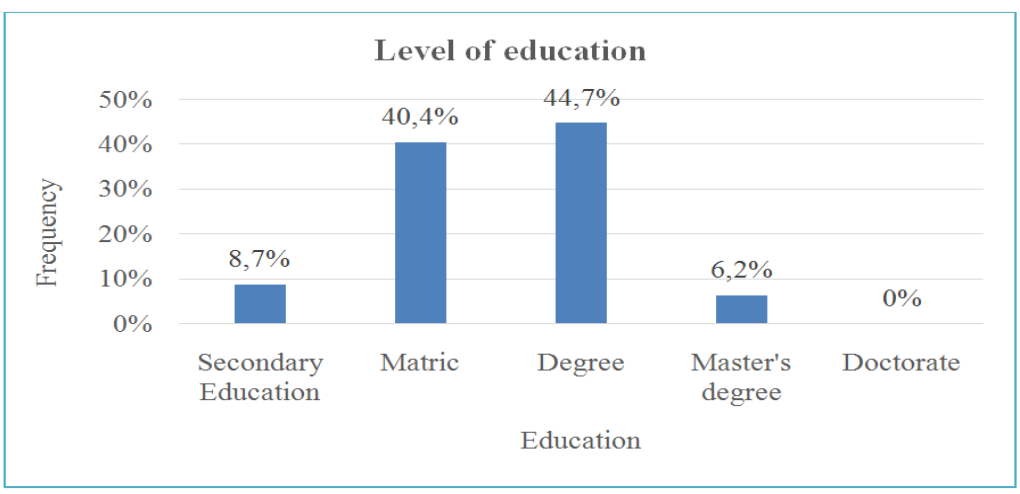

Fig. 3. Highest level of education

The results of the level of education indicate that the majority of the respondents, $44.72 \%$ have a degree. This is followed by a matric certificate at $40.4 \%$. Very few participants, $8.7 \%$ have a secondary education, while $6.2 \%$ have a Master's degree.

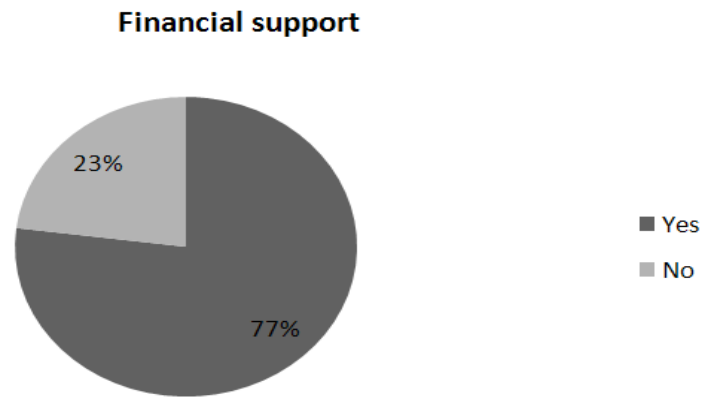

Fig. 4. Access to financial support

As displayed in Figure 4. 77.02\% of the respondents have access to financial support, while only $23 \%$ do not have access to financial support.

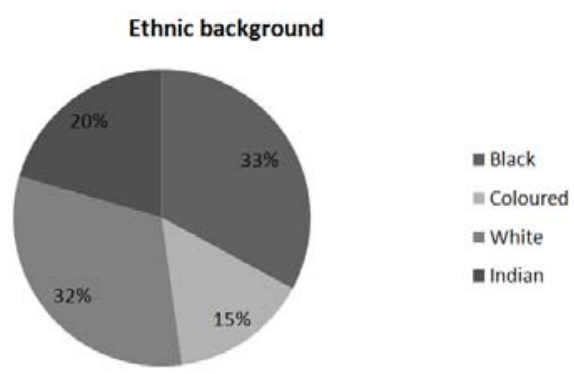

Fig. 5. Ethnic background

The Black and White groups are almost equally present amongst the participants at 33\% and 32\%, respectively. The Indians make up $20 \%$ of the group while the Coloreds are the least at $15 \%$.

Of the respondents $2.48 \%$ have been in business for not more than a year, $8.7 \%$ between 2 and 3 years, $21.12 \%$ between 4 and 5 years and the majority over 5 years at $67.7 \%$.

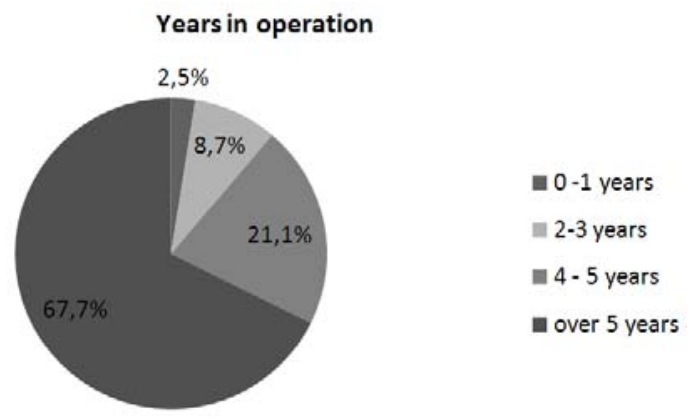

Fig. 6. Years in operation

The largest sector represented in this study is the retail sector with $42.9 \%$ of the participants. Next up is the manufacturing sector with $16.8 \%$ followed by the communications sector and the financial sector with $13.7 \%$ each. Other sectors present are the tourism sector with $6.8 \%$, the investment sector at $4.4 \%$, the agricultural sector with $1.24 \%$ and the mining sector with only $0.62 \%$. These results can be seen in Figure 7.

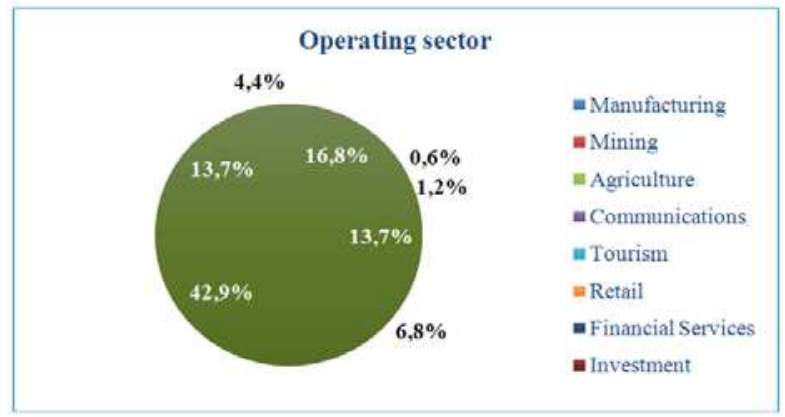

Fig. 7. Operating sector of respondents

\section{Interpretation of results}

3.1. Reliability of scale used. The validity of the questionnaire was tested using factor analysis. According to Field (2009, p. 628), factor analyses are used to identify groups or clusters of variables. He further states that the technique has three main 
uses (1) to understand the structure of a set of variables, (2) to construct a questionnaire to measure an underlying variable and (3) to reduce a data set to a more manageable size while retaining as much of the original information as possible. Reliability means that a measure, in this case, the questionnaire, should consistently reflect the construct it is measuring (Field, 2009, p. 628). Table 1 displays the Cronbach's Alpha as calculated through Cronbach's Alpha coefficient for each section of the questionnaire. According to Field (2009), Cronbach is Alpha values substantially lower than 0.7 to 0.8 does not represent an acceptable reliability level.

Table 1. Cronbach's alpha for the sub-scales of the measurement

\begin{tabular}{|l|l|l|}
\hline \multicolumn{1}{|c|}{ Section } & \multicolumn{1}{|c|}{ Measuring } & \multicolumn{1}{c|}{ Initial Cronbach's (a) alpha } \\
\hline A & Demographics & Not required \\
\hline B & Factors & Not required \\
\hline C1-C4 & Risk Behavior (Likelihood) & 0.85 \\
\hline C5-C8 & Risk Behavior (Perception) & 0.24 \\
\hline D & Economic performance & 0.81 \\
\hline
\end{tabular}

For the reliability of this measuring instrument, the Alpha coefficient was calculated for each sub scale of the variables. The results indicate that most sub scales are reliable, except for questions C5-C8 measuring the perception of risk, which had an Alpha below 0.7. For section C5-C8, the questions were recoded to group or combine data to form additional variables with less detailed categories.

\subsection{Factors that might affect risk taking-ability.} According to Field (2009, p. 688), to test the relationship between two categorical variables, the Pearson Chi-square test could be used. This test was used to determine possible relationships between the respondents' age, level of education, access to financial support, ethnic background, number of years in operation and the sector the entrepreneur operate in vs. their risk-taking ability. The risk- taking ability consists out of the likelihood to take risks, as well as the risk perception level of the activity. The results regarding these factors versus the likelihood to engage in risky activities are displayed in Tables 2 to 7 .

Table 2. Chi-square test for age in years versus likelihood to engage in risky activities

\begin{tabular}{|l|c|c|c|}
\hline \multicolumn{1}{|c|}{ Statistic } & Value & Df & $\begin{array}{c}\text { Asymp. Sig. } \\
\text { (2-tailed) }\end{array}$ \\
\hline Pearson Chi-square & 126.66 & 84 & 0.002 \\
\hline Likelihood Ratio & 69.56 & 84 & 0.871 \\
\hline $\begin{array}{l}\text { Linear-by-Linear } \\
\text { Association }\end{array}$ & 0.05 & 1 & 0.819 \\
\hline N of Valid Cases & 161 & & \\
\hline
\end{tabular}

The majority of the respondents, $46.6 \%$, are in the age group 36 to 40 years of age, with the second highest number at $28.6 \%$ in the 31 to 35 year age group. The Pearson Chi-square result is 126.66 $\left(x^{2}(84)\right)$, which is more than the critical value $(d f)$ of 84. The p-value of 0.002 is much lower than the cut off value of 0.05 . The assumption can, thus, be made that the older generation are more likely to engage in risky activities than the younger entrepreneurs.
Table 3. Chi-square test for level of education versus likelihood to engage in risky activities

\begin{tabular}{|l|c|c|c|}
\hline \multicolumn{1}{|c|}{ Statistic } & Value & Df & $\begin{array}{c}\text { Asymp. Sig. } \\
\text { (2-tailed) }\end{array}$ \\
\hline Pearson Chi-square & 67.47 & 42 & 0.008 \\
\hline Likelihood Ratio & 60.53 & 42 & 0.032 \\
\hline Linear-by-Linear Association & 26.31 & 1 & 0 \\
\hline N of Valid Cases & 161 & & \\
\hline
\end{tabular}

There is a significant association between the respondents level of education and the likelihood to engage in risky activity with $X^{2}(42)=67.47$ which is more than the critical value $(d f=42)$, as well as a $p<0.05$. In this case, the likelihood ratio $\left(L X^{2}=\right.$ $60.53)$ is also higher than the critical value $(d f=42)$.

Table 4. Chi-square test for access to financial support versus likelihood to engage in risky activities

\begin{tabular}{|l|c|c|c|}
\hline \multicolumn{1}{|c|}{ Statistic } & Value & Df & $\begin{array}{c}\text { Asymp. Sig. } \\
\text { (2-tailed) }\end{array}$ \\
\hline Pearson Chi-square & 29.62 & 14 & 0.009 \\
\hline Likelihood Ratio & 36.82 & 14 & 0.001 \\
\hline Linear-by-Linear Association & 9.59 & 1 & 0.002 \\
\hline N of Valid Cases & 161 & & \\
\hline
\end{tabular}

To the question whether the respondents have access to financial support, $77.02 \%$ responded positively. The Chi-square test results at $x^{2}(14)=$ 29.62 is more than the critical value $(d f=14)$. The p-value is well below 0.05 at 0.009 , while the likelihood ratio $\left(L X^{2}=36.82\right)$ is also higher than the critical value $(d f=14)$. These results indicate a significant association between the two variables. It seems, therefore, that access to financial support could lead to a higher inclination to engage in risky activities.

Table 5. Chi-square test for ethnic background versus likelihood to engage in risky activities

\begin{tabular}{|l|c|c|c|}
\hline \multicolumn{1}{|c|}{ Statistic } & Value & Df & $\begin{array}{c}\text { Asymp. Sig. } \\
\text { (2-tailed) }\end{array}$ \\
\hline Pearson Chi-square & 51.08 & 42 & 0.159 \\
\hline
\end{tabular}


Table 5 (cont.). Chi-square test for ethnic background versus likelihood to engage in risky activities

\begin{tabular}{|l|c|c|c|}
\hline \multicolumn{1}{|c|}{ Statistic } & Value & Df & $\begin{array}{c}\text { Asymp. Sig. } \\
\text { (2-tailed) }\end{array}$ \\
\hline Likelihood Ratio & 56.78 & 42 & 0.064 \\
\hline Linear-by-Linear Association & 0.27 & 1 & 0.605 \\
\hline N of Valid Cases & 161 & & \\
\hline
\end{tabular}

From Figure 5, it can be established that $65 \%$ of the respondents belong to the Black and White ethnic groups. The Chi-square result of $x^{2}(42)=51.08$ is more than the critical value $(d f=42)$. The p-value of 0.159 is more than 0.05 , and the likelihood ratio $\left(L X^{2}=56.78\right)$ is also higher than the critical value $(d f=42)$. The recorded results lead to the conclusion that there is no significant association between ethnic background and the likelihood to engage in risky activities in male entrepreneurs.

Table 6. Chi-square test for operator sector versus likelihood to engage in risky activities

\begin{tabular}{|l|c|c|c|}
\hline \multicolumn{1}{|c|}{ Statistic } & Value & Df & $\begin{array}{c}\text { Asymp. Sig. } \\
\text { (2-tailed) }\end{array}$ \\
\hline Pearson Chi-square & 132.51 & 98 & 0.012 \\
\hline Likelihood Ratio & 109.57 & 98 & 0.2 \\
\hline $\begin{array}{l}\text { Linear-by-Linear } \\
\text { Association }\end{array}$ & 1.46 & 1 & 0.228 \\
\hline N of Valid Cases & 161 & & \\
\hline
\end{tabular}

For this factor, there is a significant association between the respondents operating sector and their risk-taking ability. The Chi-square result, $x^{2}(98)=132.51$, is more than the critical value $(d f=$ 98), while $p<0.05$. The likelihood ratio $\left(L X^{2}=109.57\right)$ is once again higher than the critical value $(d f=98)$. The results from section 1 indicate that the majority of the respondents at $42.9 \%$ operate within the retail sector. As the association is significant the assumption can be made that entrepreneurs within this section are more likely to engage in risky activities than entrepreneurs within the other sectors.

Table 7. Chi-square test for years in operation versus likelihood to engage in risky activities

\begin{tabular}{|l|c|c|c|}
\hline \multicolumn{1}{|c|}{ Statistic } & Value & Df & $\begin{array}{c}\text { Asymp. Sig. } \\
\text { (2-tailed) }\end{array}$ \\
\hline Pearson Chi-square & 105.76 & 42 & 0.000 \\
\hline Likelihood Ratio & 75.32 & 42 & 0.001 \\
\hline $\begin{array}{l}\text { Linear-by-Linear } \\
\text { Association }\end{array}$ & 18.91 & 1 & 0.000 \\
\hline N of Valid Cases & 161 & & \\
\hline
\end{tabular}

There is a significant association between the respondents years in operation and their risk-taking ability $X^{2}(42)=105.76$ and is more than the critical value $(d f=42)$, as well as a $p<0.05$. In this case, the likelihood ratio $\left(L X^{2}=75.32\right)$ is also higher than the critical value $(d f=42)$. The results indicate that entrepreneurs with a longer career will be more likely to engage in risky activities.
The recorded results indicate a strong relationship between all variables tested against the likelihood to engage in risky activities. The exception is the ethnic background, which had an $X^{2}>d f$, although the $p$-value at the $95 \%$ level confidence is not lower than 0.05 . The next section gives the results with regards to factors which might affect the risk perception of the activity.

Table 8. Age versus risk perception

\begin{tabular}{|l|c|c|c|}
\hline \multicolumn{1}{|c|}{ Statistic } & Value & Df & $\begin{array}{c}\text { Asymp. Sig. } \\
\text { (2-tailed) }\end{array}$ \\
\hline Pearson Chi-square & 0.45 & 5 & 0.994 \\
\hline Likelihood Ratio & 0.71 & 5 & 0.982 \\
\hline Linear-by-Linear Association & 0.19 & 1 & 0.661 \\
\hline N of Valid Cases & 161 & & \\
\hline
\end{tabular}

There is no significant association between the respondents age and risk perception $\left(X^{2}(5)=0.45\right.$ and is not more than the critical value $(d f=5)$, as well as a $p>0.05$. The results indicate that age levels did not affect the respondents risk perception.

Table 9. Education level vs. risk perception

\begin{tabular}{|l|c|c|c|}
\hline \multicolumn{1}{|c|}{ Statistic } & Value & Df & $\begin{array}{c}\text { Asymp. Sig. } \\
\text { (2-tailed) }\end{array}$ \\
\hline Pearson Chi-square & 6.06 & 3 & 0.109 \\
\hline Likelihood Ratio & 7.41 & 3 & 0.06 \\
\hline Linear-by-Linear Association & 1.75 & 1 & 0.186 \\
\hline N of Valid Cases & 161 & & \\
\hline
\end{tabular}

There is no significant association between the respondent's education level and their risk perception. Although $X^{2}(3)=6.06$ and is more than the critical value $(d f=3), p>0.05$. The results indicate that education level does not affect respondents risk perception.

Table 10. Access to financial support versus risk perception

\begin{tabular}{|l|c|c|c|}
\hline \multicolumn{1}{|c|}{ Statistic } & Value & Df & $\begin{array}{c}\text { Asymp. Sig. } \\
\text { (2-tailed) }\end{array}$ \\
\hline Pearson Chi-square & 1.22 & 1 & 0.269 \\
\hline Likelihood Ratio & 2.12 & 1 & 0.145 \\
\hline Continuity Correction & 0.25 & 1 & 0.614 \\
\hline Linear-by-Linear Association & 1.22 & 1 & 0.27 \\
\hline N of Valid Cases & 161 & & \\
\hline
\end{tabular}

There is no significant association between the respondent's access to financial support and their risk perception. Although $X^{2}(1)=1.22$ and is more than the critical value $(d f=1), p>0.05$. The results indicate that access to financial support does not affect the respondents risk perception.

Table 11. Ethnic background versus risk perception

\begin{tabular}{|l|c|c|c|}
\hline \multicolumn{1}{|c|}{ Statistic } & Value & Df & $\begin{array}{c}\text { Asymp. Sig. } \\
\text { (2-tailed) }\end{array}$ \\
\hline Pearson Chi-square & 2.25 & 3 & 0.522 \\
\hline Likelihood Ratio & 3.55 & 3 & 0.314 \\
\hline Linear-by-Linear Association & 0.49 & 1 & 0.483 \\
\hline N of Valid Cases & 161 & & \\
\hline
\end{tabular}


There is no significant association between the respondents access to financial support and risk perception $X^{2}(3)=2.25$ and is not more than the critical value $(d f=3)$, as well as a $p>0.05$. The results indicate that ethnic background does not affect the respondents risk perception.

Table 12. Operating sector versus risk perception

\begin{tabular}{|l|c|c|c|}
\hline \multicolumn{1}{|c|}{ Statistic } & Value & Df & $\begin{array}{c}\text { Asymp. Sig. } \\
\text { (2-tailed) }\end{array}$ \\
\hline Pearson Chi-square & 3.16 & 7 & 0.87 \\
\hline Likelihood Ratio & 4.64 & 7 & 0.703 \\
\hline Linear-by-Linear Association & 1.53 & 1 & 0.216 \\
\hline N of Valid Cases & 161 & & \\
\hline
\end{tabular}

There is no significant association between the respondents operating sector and risk perception $X^{2}(7)=3.16$ and is not more than the critical value $(d f=7)$, as well as a $p>0.05$. The results indicate that the sector in which the respondent operates in does not affect their risk perception.

Table 13. Number of years in operation versus risk perception

\begin{tabular}{|l|c|c|c|}
\hline \multicolumn{1}{|c|}{ Statistic } & Value & Df & $\begin{array}{c}\text { Asymp. Sig. } \\
\text { (2-tailed) }\end{array}$ \\
\hline Pearson Chi-square & 1.96 & 3 & 0.581 \\
\hline Likelihood Ratio & 3.17 & 3 & 0.366 \\
\hline Linear-by-Linear Association & 1.51 & 1 & 0.22 \\
\hline N of Valid Cases & 161 & & \\
\hline
\end{tabular}

There is no significant association between the respondents number of years in operation and risk perception $X^{2}(3)=1.96$ and is not more than the critical value $(d f=3)$, as well as a $p>0.05$. The results indicate that the number of years in operation does not affect the respondents risk perception.

The results indicate that there is no significant association between the factors identified and the respondents risk perception.

\section{Risk-taking ability versus economic performance}

In order to further establish factors that will influence risk taking behavior of entrepreneurs, the relationship between the likelihood of engaging in risky activities was tested against their economic performance.

Table. Likelihood to take risk versus economic performance

\begin{tabular}{|l|c|c|c|}
\hline \multicolumn{1}{|c|}{ Statistic } & Value & Df & $\begin{array}{c}\text { Asymp. Sig. } \\
\text { (2-tailed) }\end{array}$ \\
\hline Pearson Chi-square & 412.68 & 280 & 0 \\
\hline Likelihood Ratio & 213.24 & 280 & 0.999 \\
\hline Linear-by-Linear Association & 7.2 & 1 & 0.007 \\
\hline N of Valid Cases & 161 & & \\
\hline
\end{tabular}

There is a significant association between the respondents likelihood to engage in risky behavior and their economic performance as $X^{2}(280)=412.68$ and more than the critical value $(d f=280)$, as well as a $p<$
0.05 , the likelihood ratio, however, $\left(L X^{2}=213.24\right)$ is not smaller than the critical value $(d f=280)$.

Furthermore, the results indicate that $52.16 \%$ of the respondents fall with the economic performance ranges of business stage at "success".

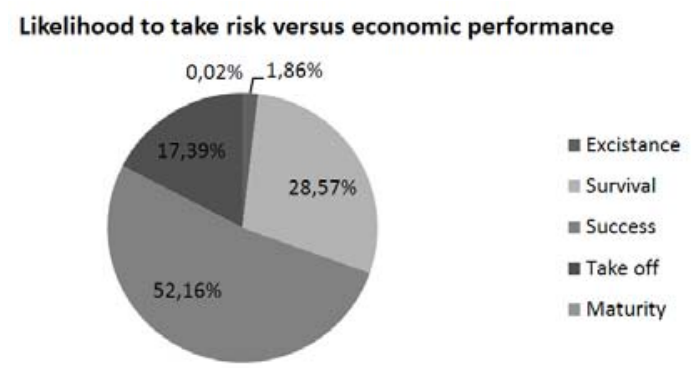

Fig. 8. Likelihood to take risk versus economic performance

This also means that their business performance can be classified as cash flow increasing moderately, the market share increasing moderately, sales growth between $10 \%$ and 19\%, sales between R100 001 and R250 000, earnings between R50 001 and R100 000 and nett worth between R100 001 and R250 000. As the Chi-square tests indicate significance between likelihood to take risk and economic performance, the results indicate the more likely the respondents are to engage in risky behavior, their performance is favorable. Secondly, the respondents perception towards the level of risk involved was tested against their economic performance.

Table 15. Perception of risk versus economic performance

\begin{tabular}{|l|c|c|c|}
\hline \multicolumn{1}{|c|}{ Statistic } & Value & df & $\begin{array}{c}\text { Asymp. Sig. } \\
\text { (2-tailed) }\end{array}$ \\
\hline Pearson Chi-square & 38.42 & 20 & 0.008 \\
\hline Likelihood Ratio & 19.39 & 20 & 0.497 \\
\hline Linear-by-Linear Association & 3.58 & 1 & 0.059 \\
\hline N of Valid Cases & 161 & & \\
\hline
\end{tabular}

There is a significant association between the respondents perception of the risk involved and their economic performance as $\left(\mathrm{X}^{2}(20)=38.42\right.$ and is more than the critical value ( $\mathrm{df}=20)$, as well as a $\mathrm{p}$ $<0.05$. The result indicates that the respondents risk perception will affect their risk perception. Furthermore, the frequency table with regards to respondents risk perception was as follows:

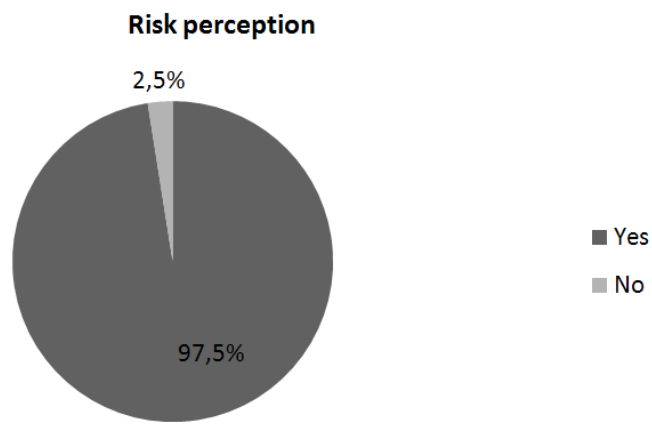

Fig. 9. Risk perception frequency table 
Figure 10 indicates that the majority of the respondents viewed the activities as risky. 52.16\% of the respondents fell within the ranges of business stage at "success".

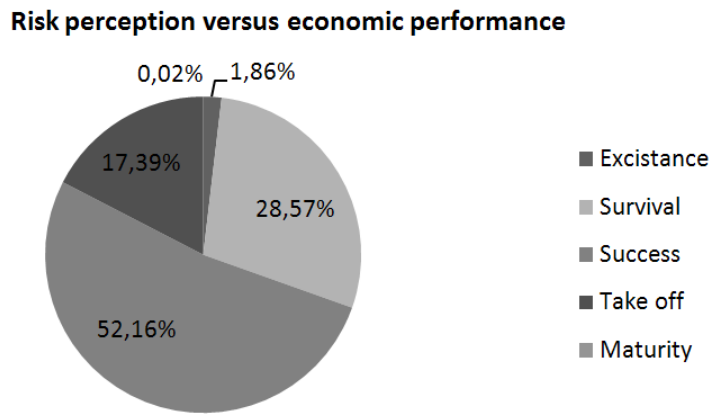

Fig. 10. Risk perception versus economic performance

This also means their business performance can be classified as cash flow increasing moderately, the market share increasing moderately, sales growth between $10 \%$ and 19\%, sales between R100 001 and R250 000, earnings between R50 001 and R100 000 and nett worth between R100 001 and R250 000. As the Chi-square tests indicate significance between risk perception and economic performance, the results indicate that the high risk perception does not seem to influence business performance negatively.

\section{Conclusions, recommendations}

The factors which might affect the risk-taking behavior of male entrepreneurs within the Centurion CBD have been studied. Their risk-taking behaviors versus their economic performance have also been investigated. The study entailed analyzing the data through descriptive statistics, multiple regression analysis factor identification and testing of reliability. Sections A were recoded into one variable, as well as Section C5 to C8 for reliability purposes. Descriptive statistics were used to analyze the biographical data and the factor identification. Multiple regression analysis studied the relationship between risk-taking behavior and economic performance. Reliability was established through Cronbach's Alpha coefficient, which was applied to test the consistency of the data. The researcher could determine the relevance of possible factors which affect risk-taking behavior, as well as male entrepreneurial behavior in relation to their economic performance. In the following chapter, these findings are being discussed and, based on the results, conclusions are drawn and recommendations given.

\section{Recommendations for future research}

This study focused on a small geographical area within South Africa. The study could be conducted over a bigger sample size in a wider area, in order to confirm or reject the findings.

The findings with regards to Hypothesis 1 could provide valuable information to insurers and capital lenders to businesses. They can assist to evaluate the risk profile of the applicant, according to the factors identified during this study. Bearing in mind the databases available for the literature review of this study, limited literature could be found with regards to Hypothesis 2, whether association exists between entrepreneurial risk-taking and economic performance. This suggests that similar studies have not been done in South Africa or abroad. The recommendation is, therefore, that further studies should be done on this topic in order to accept or reject the findings of this study.

\section{References}

1. Ahmed, S.U. (1985). Risk-taking Propensity, Locus of Control and Entrepreneurship, Personality and Individual Differences, 6, pp. 781-782.

2. Anderson, B.S. \& Eshima, Y. (2013). The influence of firm age and intangible resources on the relationship between entrepreneurial orientation and firm growth among Japanese SMEs, Journal of Business Venturing, 28, pp. 413-429.

3. Appelt, K.C., Milch, K.F., Handgraaf, M.J.J. \& Weber, E.U. (2011). The Decision Making Individual Differences Inventory and guidelines for the study of individual differences in judgment and decision-making research, Judgment and Decision Making, 6, pp. 252-262.

4. Babbie, E. \& Mouton, J. (2001). The practice of social research. Cape Town: Oxford University Press.

5. Bateman, T.S. \& Crant, M.J. (1993). The Proactive Component of Organizational Behavior, Journal of Organizational Behavior, 14(2), pp. 103-118.

6. Barbosa, S.D., Gerhardt, M.W. \& Kickul, J.R. (2007). The Role of Cognitive Style and Risk Preference on Entrepreneurial Self-Efficacy and Entrepreneurial Intentions, Journal of Leadership and Organizational Studies, 13(4), pp. 86-104.

7. Begley, T. \& Boyd, D. (1987). A comparison of entrepreneurs and managers of small business firms, Journal of Management, 13(1), pp. 99-108.

8. Blais, A.R. \& Weber, E.U. (2006). A Domain-Specific Risk-Taking (DOSPERT) scale for adult populations, Judgment and Decision Making, 1(1), pp. 33-47.

9. Brockhaus, R.H. (1980). Risk taking propensity of entrepreneurs, Academy of Management Journal, 23(3), pp. 509-520.

10. Brockhaus, R.H. (1987). Entrepreneurial folklore, Journal of Small Business Management, 25(3), pp. 1-6. 
11. Business Dictionery. [Online]. Available from: http://www.businessdictionary.com/definition/cash-flow.html. [Accessed: 17/09/2015].

12. Byrnes, J.P., Miller, D.C. \& Schafer, W.D. (1999). Gender Differences in Risk Taking: A Meta-Analysis, Psychological Bulletin, 125(3), pp. 367-383.

13. Caliendo, M., Fossen, F. \& Kritikos, A. (2010). The impact of risk attitudes on entrepreneurial survival, Journal of Economic Behavior and Organization, 76, pp. 45-63.

14. Carland, J., Carland, J.W. \& Stewart, W.H. (1996). Seeing what's not there: The enigma of entrepreneurship, Journal of Small Business Strategy, 7(1), pp. 1-20.

15. Carland, J.W. Iii, Carland, J.W., Carland, J.C. \& Pearce, J.W. (1995). Risk taking propensity among entrepreneurs, small business owners, and managers, Journal of Business and Entrepreneurship, 7(1), pp. 15-23.

16. Chandler, G.N. \& Hanks, S.H. (1993). Measuring the performance of emerging businesses: a Validation study, Journal of business venturing, 8, pp. 391-408.

17. Chen, S.U. \& Wu, S. (2012). Need for achievement, education, and entrepreneurial risk-taking behavior, Social behavior and personality, 40(8), pp. 1311-1318.

18. Churchill, N.C. \& Lewis, V.L. (1983). The five stages of small business growth, Harvard Business Review, 83(3), pp. 3-12.

19. Cooper, D.R. \& Schindler, P.S. (2011). Business Research Methods. 11th ed. London: McGraw-Hill.

20. Crant, M.J. (1996). The proactive personality scale as a predictor of entrepreneurial intentions, Journal of Small Business Management, 34(3), p. 42.

21. Cunningham, J.B. \& Lischeron, J. (1991). Defining entrepreneurship, Journal of Small Business Management, 29(1), pp. 45-61.

22. Curry, J.G. (2014). A closer look at entrepreneurship and attitude toward risk. M. Arts. Thesis, Graduate College of Bowling Green State University.

23. Evans, D.S. \& Jovanovic, B. (1989). An estimated model of entrepreneurial choice under liquidity constraints, The Journal of Political Economy, 97(4), pp. 808-827.

24. Field, A. (2009). Discovering statistics using SPSS. London: SAGE.

25. Forlani, D. \& Mullins, J.W. (2000). Perceived risks and choices in entrepreneur's new venture decisions, Journal of business venturing, 15, pp. 305-322.

26. Funk \& Wagnall (1958). Standard dictionary. New York: Funk \& Wagnall's Co.

27. Gomez-Mejia, L.R. \& Balkin, D.B. (1989). Effectiveness of individual and aggregate compensation strategies, Industrial Relations, 28(3), pp. 431-445.

28. Grable, J.E. (2000). Financial risk tolerance and additional factors that affect risk taking in everyday money matters, Journal of Business and Psychology, 14(4), pp. 625-630.

29. Hair, J.F., Celsi, M.W., Money, A.H., Samouel, P. \& Page, M.J. (2011). Essentials of business research methods. 2nd ed. London: M.E. Sharpe.

30. Investor Words [Online]. Available from: http://www.investorwords.com/3259/net_profit.html [Accessed: 17/09/2015].

31. Keil, M., Wallace, L., Turk, D., Dixon-Randol, G. \& Nulden, U. (1998). An investigation of risk perception and risk propensity on the decision to continue a software development project, Journal of Systems and Software, 53, pp. $145-157$.

32. Kgomo, F.L. (2010). Employee engagement model facilitating agent retention in the contract centre industry. D.Tech. Dissertation, Pretoria, Tshwane University of Technology.

33. Koh, H.C. (1996). Testing hypothesis of entrepreneurial characteristics. A study of Hong Kong MBA students, Journal of Managerial Psychology, 11, pp. 12-25.

34. Kruas, S.I., Frese, M., Friedrich, C. \& Unger, J.M. (2005). Entrepreneurial orientation: A psychological model of success among southern African small business owners, European Journal of Work and Organizational Psychology, 14(3), pp. 315-344.

35. Levitt, T. (1990). Top line thinking at the NEA, The Wall Street Journal, June 28.

36. Li, S. \& Fang, Y. (2004). Respondents in Asian Cultures (e.g., Chinese) are More Risk-Seeking and More Overconfident than Respondents in Other Cultures (e.g., in United States) but the Reciprocal Predictions are in Total Opposition: How and Why? Journal of Cognition and Culture, 4(2), pp. 263-292.

37. Long, W. (1983). The meaning of entrepreneurship, American Journal of Small Business, 8, pp. 47-56.

38. Macko, A. \& Tyszka, T. (2009). Entrepreneurship and Risk Taking, Applied psychology: an International Review, 58(3), pp. 469-487.

39. March, J.G. \& Shapira, Z. (1987). Managerial perspectives on risk and risk taking, Management Science, 33(11), pp. 1404-1418.

40. Miao, Q. \& Liu, L. (2010). A Psychological model of entrepreneurial decision making, Social Behavior and Personality, 38(3), pp. 357-364.

41. Oosterbeek, H., Van Praag, V.M. \& Ijsselstein, A. (2010). The impact of entrepreneurship education on entrepreneurship skills and motivation, European Economic Review, 54, pp. 442-454.

42. Palich, L.E. \& Bagby, D.R. (1995). Using cognitive theory to explain entrepreneurial risk-taking: challenging conventional wisdom, Journal of Business Venturing, 10(8), pp. 425-438. 
43. Richard, J.C. (1989). A comparison of the social characteristics, personalities, and managerial styles of managers and entrepreneurs. Unpublished doctoral dissertation. Canada, University of Windsor.

44. Saunders, M., Lewis, P. \& Thornhill, A. (2012). Research methods for business students. $6^{\text {th }}$ ed. Cape Town: Pearson.

45. Shane, S., Locke, E.A. \& Collins, C.J. (2003). Entrepreneurial motivation, Human Resource Management Review, 13(2), pp. 257-279.

46. Simon, M., Houghton, S.M. \& Aquino, K. (1999). Cognitive biases, risk perception, and venture formation: how individuals decide to start companies, Journal of Business Venturing, 15, pp. 113-134.

47. Sitkin, S.B. \& Pablo, A.L. (1992). Reconceptualizing the determinants of risk behavior, Academy of Management Review, 17(1), pp. 9-38.

48. Sitkin, S.B. \& Weingart, L.R. (1995). Determinants of risky decision-making behavioral test of the mediating role of risk perceptions and propensity, Academy of Management, 38 (6), pp. 1573-1592.

49. Spinelli, J.R. \& Adams, R. (2012). New Venture creation. Entrepreneurship for the $21^{\text {st }}$ Century. New York.

50. Stewart, W.H., Watson, W.E., Carland, J.C. \& Carland, J.W. (1999). A proclivity for entrepreneurship: A comparison of entrepreneurs, small business owners, and corporate managers, Journal of Business Venturing, 14, pp. 189-214.

51. Tyszka, T., Cieslik, J., Domuratc, A. \& Mackoa, A. (2011). Motivation, self-efficacy, and risk attitudes among entrepreneurs during transition to a market economy, The Journal of Socio-Economics, 40, pp. 124-131.

52. Urvi, N. (2010). Estimation and impact of gender differences in risk tolerance, Economic Inquiry, 48(1), pp. $228-233$.

53. Vogt, W.P. \& Johnson, R.B. (2011). Dictionary of statistics and methodology. 4th ed. London: Sage Publications Inc.

54. Weber, E.U., Blais, A.R. \& Betz, N.E. (2002). A domain-specific risk-attitude scale: measuring risk perceptions and risk behaviors, Journal of Behavioral Decision Making, 15(4), pp. 263-290.

55. Weber, E.U. \& Hsee, C. (1998). Cross-Cultural Differences in Risk Perception, but Cross-Cultural Similarities in Attitudes towards Perceived Risk, Management Science, 44(9), pp. 1205-1217.

56. Weber, E.U. \& Hsee, C. (1998). What folklore tells us about risks and risk taking: Cross-Cultural Comparisons of American, German and Chinese proverbs,Organisational Behavior and Human Decision Processes, 75(2), pp. 170-186.

57. Weber, E.U., Hsee, C.K. \& Sokolowska, J. (1998). What folklore tells about risk and risk taking? Cross-cultural comparisons of American, German and Chinese proverbs, Organizational Behavior and Human Decision Processes, 75, pp. 170-186.

58. Webster's third new international dictionary (1961). Chicago: Merriam Co.

59. Welman, J.C. \& Kruger, S.J. (1999). Research methodology for business and administrative sciences. Cape Town: Oxford University Press.

60. Wiklund, J. \& Sheppard, D. (2005). Entrepreneurial orientation and small business performance: a configurational approach, Journal of Business Venturing, 20(1), pp. 71-91.

61. Willebrands, D., Lammers, J. \& Hartog, J. (2012). A successful businessman is not a gambler. Risk attitude and business performance among small enterprises in Nigeria, Journal of Economic Psychology, 33, pp. 342-354.

62. Yates, J.F., Lee, J.W. \& Bush, J.G. (1997). General knowledge overconfidence: Cross-national variations, response style, and "reality", Organizational Behavior and Human Decision Processes, 70, pp. 87-94.

63. Yates, J.F., Lee, J.W. \& Shinotsuka, H. (1996). Beliefs about overconfidence, including its cross-national variation, Organizational Behavior and Human Decision Processes, 65, pp. 138-147.

64. Yates, J.F., Lee, J.W., Shinotsuka, H., Patalano, A.L. \& Sieck, W.R. (1998). Cross-cultural variations in probability judgement accuracy: Beyond general knowledge overconfidence? Organizational Behavior and Human Decision Processes, 74, pp. 89-117.

65. Yates, J.F. \& Stone, E.R. (1992). The risk construct. England: John Wiley and Son.

66. Zinkhan, G.M. \& Karande, K.W. (1990). Cultural and gender differences in risk-taking behavior among American and Spanish decision makers, The Journal of Social Psychology, 131(5), pp. 741-742. 